\title{
REPUBLICANISMO, CONSTITUIÇÃO E PERCEPÇÃO DA JUSTIÇA NO BRASIL
}

Newton Bignotto*

Rousseau define a república como "todo Estado regido por leis sob qualquer forma que seja de administração, porque então somente o interesse público governa, e a coisa pública é uma realidade" (Rousseau, 2011, p. 90). Em sua aparente simplicidade, essa definição contém um enorme desafio na medida em que coloca no centro da construção de uma forma legítima de governo o respeito ao interesse público e o dever de torná-lo realidade.

$\mathrm{Na}$ história recente do Brasil, podemos dizer que a Constituição de 1988 é o texto que expressa nosso contrato social e que por isso contém a expressão normativa do que deveria ser o interesse público. Nesse sentido, têm razão os constitucionalistas, que insistem na necessidade de defendermos nossa Constituição como o núcleo de nosso regime republicano. A defesa da Constituição passa, no entanto, não apenas pela defesa de seu texto original, mas pela defesa de sua capacidade de expressar o interesse comum, que, como mostrou Rousseau, não pode ser confundido com a soma dos interesses privados, mas que também não pode ser alheio às mudanças pelas quais passam todas as sociedades políticas. Um dos grandes desafios à consumação do interesse público vem do fato de que nem sempre

\footnotetext{
* Doutor pela École des Hautes Études en Sciences Sociales (França), professor associado do Departamento de Filosofia da Universidade Federal de Minas Gerais (UFMG) e pesquisador do CNPq.
} 
$|34|$

Republicanismo, constituição e percepção...

ele é evidente aos olhos do cidadãos acostumados com o quadro de disputa contínua que define o conjunto de interesses que povoam a cena pública. Ora, o conflito entre interesse privado e interesse público pode ameaçar a Constituição e afetar a percepção da justiça ou de sua aplicação no cotidiano do país, e, por isso, não pode ser deixado de lado quando pensamos na defesa das leis de uma república.

É preciso notar, no entanto, que os conflitos aos quais nos referimos nem sempre concernem o texto constitucional. Ao contrário, são muitas vezes inovações legais sobre temas como pesquisas sobre células tronco, ou leis que modificam comportamentos aceitos como tradicionais, que impactam mais decisivamente a percepção da qualidade de nossas leis. O que o republicanismo de Rousseau nos ajuda a compreender é que não basta pensar as leis de um país, sua Constituição em particular, a partir de sua pura forma. Sendo o contrato social um artifício humano, e não um legado dos deuses, ele tem de ser vivido pelos habitantes de um país como algo do qual eles não podem se separar, se quiserem viver bem. Em outra linguagem, ele possui uma dimensão política, que nos ajuda a compreender porque não é a perfeição formal das leis sozinha que garante a adesão a uma Constituição e ao conjunto de leis, que definem um regime republicano. É preciso, como dizem alguns juristas, ${ }^{1}$ que a Constituição e as leis sejam vividas e se mostrem elas mesmas vivas, para atar os cidadãos aos vínculos que elas tecem. Nesse horizonte entre os fundamentos do Estado republicano e as práticas efetivas dos atores políticos crescem os valores, que guiam a vida pública, mas também as ações, que minam o contrato social e colocam em risco a democracia.

Vamos nos interessar aqui por uma das formas de ameaça ao regime republicano no Brasil, que nasce da percepção de que algumas inovações legais recentes são injustas e contrariam o que pode ser vivido como sendo a vontade da maioria. Do ponto

${ }^{1}$ Essa posição se aproxima daquela expressa em outro contexto analítico pelo jurista Menelick Carvalho Neto. 
de vista de Rousseau, esse conflito serve para mostrar a distância que separa as leis oriundas do que ele chama de vontade geral, e que dizem respeito aos fundamentos do Estado, e as simples normas, que povoam a vida na cidade, e que muitas vezes são a expressão de grupos sociais reunidos por interesses particulares. O que importa aqui é menos a distinção conceitual proposta pelo pensador francês e mais o fato de que ele nos ajuda a esclarecer a natureza dos vínculos existentes entre opinião pública e leis num Estado de direito e os caminhos e descaminhos que nascem dessa conjunção. É claro que não pretendemos apresentar uma visão de conjunto da forma como se estrutura a relação dos cidadãos brasileiros com as instituições republicanas, mas apenas sinalizar um dos empecilhos para a plena consolidação do Estado republicano entre nós. Por outro lado, pretendemos mostrar que por meio de inovações no campo do direito, que contrariam por vezes percepções caras à uma parcela importante da opinião pública, é que a democracia republicana encontra sua realização enquanto expressão dos interesses comuns.

Para levar a cabo nossa tarefa, escolhemos abordar a maneira como a legislação vigente sobre a infância e a adolescência impacta a opinião pública e gera comportamentos contrários à aceitação das transformações que ela opera na vida de nossa sociedade. Trata-se evidentemente do estudo de um caso particular, mas que pode ser útil para elucidar alguns aspectos das questões mais amplas que nos preocupam.

\section{Violência e justiça}

Com muita frequência as páginas dos jornais brasileiros são ocupadas por manchetes de crimes chocantes, que mobilizam a população por mais tempo do que os relatos cotidianos das páginas policiais. Em geral, a atenção dos órgãos de comunicação é captada por algum fato extraordinário, que ressalta a crueldade, a frieza ou até o ineditismo das ações praticadas. Nesse universo, no qual o cotidiano se transforma em espetáculo, a participação de crianças e adolescentes costuma galvanizar os olhares aflitos 
|36|

Republicanismo, constituição e percepção...

dos que procuram entender o acontecido. Nesses casos, a surpresa diante do horror aparece tanto se a vítima é uma criança quanto se algum adolescente participou como executor do crime. É possível dizer que em ambos os casos nossas reações transcendem a mera curiosidade, que costuma cercar eventos extraordinários, pela suspeita de que existe escondida na realidade imediata uma ameaça difusa, que paira sobre toda sociedade.

É óbvio que nenhuma sociedade pode encarar esse tipo de acontecimento como algo banal e nem mesmo aceitar que crimes praticados em circunstâncias fora do comum possam ser aceitos como uma fatalidade contra a qual não é possível fazer algo de positivo. Ao nos interpelar de maneira tão radical, esses acontecimentos acabam nos expondo a cenas que nos mostram os limites de compreensão de nossa sociabilidade e do próprio mundo no qual vivemos hoje. Embora reconhecendo que os fatos envolvendo crianças são em geral os que despertam os sentimentos mais intensos na população, e que não há simetria entre vítimas e executores, pelo fato dos dois eventualmente terem a mesma idade, interessa-nos aqui explorar o significado das reações que costumam acompanhar os fatos envolvendo jovens infratores. Vale a pena insistir que estamos com isso apenas operando um recorte analítico, que não supõe nenhuma hierarquia entre fatos e nem a ideia de que podemos naturalizar esse tipo de evento, sugerindo com isso que uma sociedade possa conviver passivamente como algo que a afeta tão profundamente.

O que gostaríamos de explorar é o significado das reações que acompanham a descoberta de que algo terrível foi cometido por um adolescente que, de acordo com a legislação atual, não será tratado como um adulto e não poderá ser julgado com o mesmo rigor. Nessas circunstâncias, não é raro aparecer na imprensa, e na opinião pública, a ideia de que esses atores possuem um verdadeiro direito de matar e que, por isso, estão acima das leis. Diante do fato verdadeiro de que criminosos se servem dessa situação para imputar seus crimes a menores, ou aliciam menores para a prática de delitos, coloca-se em questão ao mesmo tempo a confiança que devemos acordar às leis e a existência de uma 
especificidade dos menores, que justificaria um tratamento diferente dos outros cidadãos, quando estão envolvidos com crimes violentos. De maneira geral, ao colocar em questão a legislação atual de proteção da infância e da adolescência, seus críticos expõem implicitamente uma visão da lei, da punição e da responsabilidade dos que praticam delitos. Para muitos, é bastante razoável voltar aos tempos nos quais a simples existência do ato delituoso deveria ser a base de um processo legal, sem nenhuma consideração pelas circunstâncias que o envolvem. ${ }^{2}$

Nossa intenção não é discutir a legislação atual e seus méritos, mesmo estando convencidos de que ela apresenta grandes avanços em relação ao passado. Nossa preocupação é com a maneira como a infância e a adolescência são vistas e como ocupam um lugar no imaginário de nosso tempo, que se revela por inteiro, quando fogem da imagem estereotipada que a elas emprestamos em nosso dia a dia. Se no lugar da suposta inocência dos primeiros anos de existência, ou mesmo da turbulência dos anos da transição incômoda para a vida adulta, aparece algo que desafia o senso comum, é toda uma camada de significações que parece ruir expondo uma visão da justiça e da forma como as liberdades devem ser vividas que nos empurra para outras eras de nossa história. O que nos interessa é analisar as diversas camadas de sentidos da justiça e da liberdade que se descortinam, quando cai por terra nossa segurança com relação à forma adequada de agir diante de fatos que parecem ameaçar nossa visão de mundo de forma inexorável.

Estamos, é claro, falando da percepção das pessoas, da maneira como pensam o problema e lidam com ele, e não de como ele de fato está equacionado do ponto de vista legal. Mas o que nos interessa aqui é justamente o fato de que essa percepção cria uma imagem do adolescente infrator, que se repercute por outras esferas da vida em comum até os fundamentos do direito. Do ponto de vista da imaginação, tudo se passa como se estivéssemos

${ }^{2}$ A esse respeito os estudos de Foucault continuam sendo uma referência preciosa (Foucault, 1975, pp. 27-35). 
$|38|$

Republicanismo, constituição e percepção...

mais uma vez confrontados com o dilema exposto por Ésquilo na Eumênides (Eschyle, 1964, pp. 205-234). Na peça, Orestes, depois de matar a mãe, se refugia inicialmente em Delfos, onde demanda a proteção de Apolo, para depois se dirigir a Atenas, onde será julgado e absolvido por um tribunal instituído pela deusa protetora da cidade. Desde o início, as Erínias não aceitam a intervenção do deus que não apenas retira-lhes uma parte importante do poder que lhes fora atribuído pela tradição, mas que parece colocar em risco toda a população ao subverter os mecanismos de punição, que eram considerados os únicos eficazes num momento de eclosão da violência extrema, que jogava por terra tabus fortemente estabelecidos na sociedade da época.

O que nos interessa na peça é menos o fato de que as Erínias se revoltam desde o início contra o fato de que um assassino possa escapar da terrível vingança, que os costumes consagravam como a pena a ser executada por elas, e sim a proteção que Apolo acorda a Orestes, que permite a ele se comportar como alguém especial, mesmo diante do horror de seus atos. Dirigindo-se ao deus, as Erínias se queixam; "É dessa forma que agem os novos deuses que reinam sobre o mundo sem se preocupar com a justiça. Podemos ver esse trono cheio de sangue dos pés à cabeça, o umbigo da terra, carregado pela terrível profanação do assassinato" (ibidem, p. 215 [159-162]). Mas Apolo não estava disposto a deixar que a vingança fizesse o papel da justiça e rebate as críticas que recebe dizendo com desprezo para as deusas tenebrosas: “Vosso lugar é lá onde a justiça abate as cabeças, onde se retiram os olhos, onde se estrangula, onde se destrói o líquido seminal das crianças em flor, onde se cortam as extremidades dos membros, onde se lapida, onde gritamos terrivelmente sob estilete enfiado na coluna" (ibidem, p. 215 [177-192]).

Na sequência da tragédia, a deusa Atena, levada a interferir no conflito e a estabelecer um tribunal no qual o próprio Apolo atuará como defensor, conseguirá um acordo com as partes, que termina com a absolvição de Orestes e a incorporação das deusas tenebrosas à esfera da vida cotidiana da cidade. Essa cena é interpretada como frequência como significando a passagem de 
uma sociedade na qual a vingança é o instrumento para a reparação dos crimes para aquelas nas quais reina o direito e a justiça formal. A própria deusa, aliás, se dirige aos habitantes de Atenas para convencê-los a honrar as Erínias em termos inequívocos: "Eu vejo que a presença dessas terríveis figuras trará para minha cidade uma grande vantagem. Sim, se, retribuindo-lhes o amor pelo amor, vocês lhes renderem sempre grandes homenagens, vocês se notabilizarão por conduzir sempre vosso país e vossa cidade no caminho direto da justiça" (ibidem, p. 233 [984-989]).

A passagem ao reino do direito, ou a superação das amarras da vingança pela instituição da justiça explicitada em formas legais reconhecíveis por todos, modifica não apenas a forma como os crimes são punidos, mas também a noção de pessoa com a qual se deve operar a partir do momento em que o processo legal expande o tempo entre o ato criminoso e a punição ou a absolvição. Essa dilatação do tempo é um dos grandes ganhos do direito, pois ela afasta a tentação própria da emoção, que suscitam os crimes que interpelam os grupos humanos no imaginário que os constitui como uma unidade. Como resume Gernet, refletindo sobre o surgimento do direito na Grécia: "Pois o direito, mesmo quando recolhe a herança das antigas solidariedades, ele as ultrapassa. Em um novo meio aparece um novo tipo de relação, justamente aquele no qual podemos individualizar o contrato" (Gernet, 1982, p. 112). Orestes só pode ser absolvido por que teve tempo para se explicar, porque pode inserir seu ato em um novo universo de significação, capaz de retirar-lhe o horror provocado por todo crime de sangue. Como sintetiza Gernet: "Em geral, e por comparação, nós diríamos que o pensamento jurídico é um pensamento abstrato e positivo, quer tenha por objeto coisas, pessoas ou relações" (ibidem, p. 113).

No caso da prática de crimes por menores, tudo se passa como se as Erínias, colocadas a serviço da cidade pela deusa encarregada de instituir a justiça, despertassem de seu estado letárgico de confinamento na memória da criação do direito, para tentar recuperar seu antigo poder de punição e vingança. 
$\mid 40$ |

Republicanismo, constituição e percepção...

O infrator que não pode ser punido, aos olhos de uma parcela da opinião pública (como ela acredita que deveria ser), é visto como um novo Orestes que, depois de ameaçar a sociedade com um crime, que não pode ser aceito, a coloca em questão ao reivindicar para si um privilégio, que nunca lhe seria acordado se as potentes deusas estivessem no comando dos mecanismos de punição. Essa operação de questionamento da lei afeta não somente a compreensão de como o crime atinge a sociedade, mas, sobretudo, de como a sociedade deve lidar com ele. De forma muito direta, ao clamar por uma punição exemplar, a parte da sociedade que adere ao protesto clama pela volta das Erínias e coloca em questão a própria noção de direito que desde a Grécia antiga estruturou a ideia de uma civilização que se quer diferente daquelas incapazes de mediar suas relações sem o recurso imediato à força. Como resume muito bem Paul Ricoeur: “Uma função maior do direito é o tratamento dos conflitos e a substituição do Discurso da violência. Toda ordem jurídica pode ser colocada sob a égide dessa substituição" (Ricoeur, 2005, p. 29).

\section{Justiça distributiva e igualdade}

Diante do espanto provocado por crimes violentos, que aos olhos da opinião pública arriscam ficar impunes, poderíamos dizer que ela até aceita tratá-los sob a ótica da justiça, mas age como as Erínias, que em hipótese alguma aceitam ver os novos Orestes serem absolvidos ou punidos de forma diferente do restante dos cidadãos. Nessa lógica, apenas a ideia da justiça corretiva, aquela encarregada de punir, sobrevive. A ideia de uma justiça distributiva, que aceita o fato de que se quisermos ser justos em um dado contexto, teremos de recorrer a distinções internas ao corpo político, nem mesmo é aceita como razoável. Isso não ocorre somente no campo dos direitos das crianças e dos adolescentes, mas, como mostra Francis Wolff (2009, pp. 6769), em todos os campos da justiça distributiva. Para ele, a justiça corretiva fica de fora das críticas dirigidas aos direitos que distinguem os membros do corpo político, porque ela "não é 
moral, é de tipo utilitarista: a necessidade da ordem social implica que todas as infrações à lei comum sejam punidas na proporção da gravidade dos danos cometidos ou dos prejuízos sofridos pelas vítimas" (ibidem, p. 68).

Vale a pena discutir por que a questão da infância e da adolescência é um problema que deve ser abordado como parte da justiça distributiva. Desde Aristóteles a distinção entre as duas formas de justiça costuma conduzir os debates acerca da natureza do que é o justo. Para o pensador grego: “Todos os homens reconhecem, de fato, que a justiça distributiva deve se basear em um mérito qualquer, ainda que nem todos concordem quanto à natureza desse mérito" (Aristote, 1987, p. 228). O problema está justamente em encontrar um critério segundo o qual o mérito deve ser reconhecido. Podemos até nomear um critério abstrato e reconhecer, como faz Aristóteles, que: "O justo em questão é a proporção, o injusto aquilo que está fora da proporção" (ibidem, p. 231). Essa operação não apaga, no entanto, a dificuldade de encontrar um critério para a justa distribuição dos bens de uma dada sociedade. Isso fica explícito diante do fato de que as diversas maneiras de julgar o mérito, e as diferenças que daí decorrem, não podem ser anuladas por uma operação lógica. Até hoje não é fácil, por exemplo, justificar por que é justo ajudar os mais pobres em uma sociedade que acredita que todos podem trabalhar por sua boa fortuna.

Muito diferente é o caso da justiça corretiva, pois, como já lembrava Aristóteles: "A lei só se preocupa como o caráter distintivo do dano causado e trata as partes de maneira igual, se perguntando somente se uma cometeu uma injustiça e se a outra a sofreu, ou se uma é o autor e a outra a vítima do dano sofrido" (ibidem, p. 233). Fica evidente que a prática de crimes parece dever ser matéria exclusiva da justiça corretiva, que não deveria ser afetada por nenhum julgamento de mérito, que implicasse numa atenuação da responsabilidade do criminoso. Como se trata de uma cena na qual as partes e os danos são hipoteticamente identificáveis, não haveria razão para lançar mão de uma ideia qualquer de justiça distributiva, uma vez que a proporção deveria 
|42|

Republicanismo, constituição e percepção...

ser de natureza aritmética, como queria o pensador grego, e não geométrica, como sugerem alguns pensadores.

Ora, a existência de um estatuto que diferencia crianças e adolescentes de adultos, mesmo do ponto de vista penal, aparece como uma intervenção indevida, aos olhos de seus críticos, de um julgamento de mérito onde deveria prevalecer a mais pura isonomia. $\mathrm{O}$ estabelecimento de uma diferença, que interfere em todas as esferas da vida comum soa, portanto, como uma injustiça, que afeta a própria ideia do direito como regulador dos conflitos. É por isso que a vingança, essa cena anterior ao contrato que funda a lei, parece se impor, quando a lei falha em produzir uma correção dos males produzidos por atores sociais que deveriam, aos olhos da opinião, ser tratados como absolutamente iguais. Como sugere Ricoeur: “É em virtude dessa inteligibilidade potencial que civilizações inteiras puderam admitir que não se colocar em cólera, não querer se vingar, não tentar executar o desejo colérico de vingança era enquanto tal um ato injusto, vergonhoso, ruim" (Ricoeur, 2005, p. 41).

O problema, portanto, com o tratamento diferente às crianças e aos adolescentes não está no fato de que eles ainda não atingiram um grau adequado de consciência para agir na cena pública. Como na Grécia antiga, até se admite considerá-los como inimputáveis e, portanto, fora do mundo pleno dos direitos, mas não como portadores de direitos que os protejam da força da justiça corretiva, ou que a apliquem levando em consideração as peculiaridades da condição resultante da idade. O desafio lançado às sociedades, como a nossa, que admitem diferenciar suas crianças e adolescentes está no fato de que isso não as coloca à margem da lei, mas sim em suas margens e, mais precisamente, próximas da fonte mesma do direito. Alterar o estatuto de parte dos membros do corpo político corresponde a relançar o debate sobre a natureza do contrato, ou para usar o termo atual, da Constituição sob a qual queremos viver. A questão não está na esfera da penalidade, ou do código penal, mas da Constituição, das regras gerais segundo às quais estruturamos nossas vidas em comum. 
É nesse sentido que a exigência de julgar crianças em acordo com os princípios da justiça corretiva implica na recusa de sua especificidade e do impacto que isso tem em toda a estrutura legal. O simples reconhecimento da pertinência de um estatuto como o existente é já uma intervenção na noção de justiça que acreditamos que deve presidir nossas vidas. Ora, não há como falar de justiça distributiva sem colocar em questão a natureza do contrato e a imagem da sociedade na qual desejamos viver. Não é possível, por exemplo, criar um estatuto que proteja apenas aqueles que não cometem infrações, deixando nas mãos da justiça corretiva a tarefa de lidar com aqueles que cometem desvios. Essa operação devolveria o problema para uma esfera na qual ele já está equacionado, seja por uma forma aritmética de equilíbrio entre dano e punição, seja pela exclusão pura e simples do infrator da esfera do direito pleno. $\mathrm{O}$ reconhecimento do estatuto diferenciado das crianças e adolescentes no interior das leis é a aceitação do fato de que o movimento histórico nessa direção acabou por afetar os fundamentos da lei e com isso exige uma mudança na forma com pensamos a justiça em suas várias acepções.

\section{Liberdade e Justiça}

Voltemos agora nosso olhar para o problema da liberdade e para a maneira como sua concepção é alterada pela admissão legal da particularidade da infância e da adolescência. Na modernidade, muitos defensores da suspensão da ideia de maioridade penal, e até mesmo de um código de proteção da infância, retiram seus argumentos de um uso astucioso da concepção de liberdade exposta ainda no século XIX por John Stuart Mill em seu célebre escrito sobre o tema. Quando Mill escrevia, o problema da infância fazia parte dos debates europeus sobre sua inclusão no mundo do trabalho, em particular na Inglaterra e na França. Conhecemos bastante bem a história da exploração do trabalho infantil, que infelizmente se estende entre nós até os dias atuais. No entanto, esse não era o tema do pensador inglês, que procurava fixar as bases de uma liberdade que não 
$|44|$

Republicanismo, constituição e percepção...

pudesse ser atacada pelas contingências do mundo do trabalho e da produção, e pudesse resistir aos ataques daqueles que temiam uma extensão dos direitos ao conjunto dos cidadãos. Mill diz no capítulo inicial de sua obra: "As preferências e aversões da sociedade, ou de alguma parte poderosa dela, constituem, assim, a principal determinante das normas estatuídas para observância geral, sob as penalidades da lei ou da opinião" (Mill, 1991, p. 51). Partindo desse ponto de vista coletivo como de uma baliza para o estabelecimento dos direitos, Mill insistia, entretanto, que os limites necessários à liberdade dos indivíduos só poderiam ser mobilizados caso eles interferissem com os direitos do restante do corpo social. A noção fundamental em seu sistema de pensamento era, portanto, aquela de indivíduo e era em torno dela que ele procurava encontrar os princípios de uma sociedade livre (ibidem, pp. 97-98). (Na esteira dessa percepção do lugar do indivíduo como núcleo das sociedades livres, ele concluía que: “O segundo preceito consiste em que, por aquelas ações prejudiciais aos interesses alheios, o indivíduo é responsável, e pode ser sujeito à punição, tanto social como legal, se a sociedade julga que a sua defesa requer uma ou outra" (ibidem, p. 137).

Considerando as bases do pensamento de Mill como aquelas de uma sociedade liberal, muitos pensadores acreditam que não há razão para estabelecer distinções entre membros do corpo político, sobretudo quando se trata de punir crimes violentos. A matriz social sendo o indivíduo, não há porque pensar em diferenças de responsabilidade, quando o ato é praticado por indivíduos conscientes de suas consequências. Em nosso tempo, pensam alguns, essa consciência é despertada muito cedo e, por isso, o direito deve se estender igualmente a todos. Nessa lógica, a implementação, pelo Estado, de políticas de proteção à infância e à adolescência são válidas se contribuem para o bem-estar social, mas não deveriam valer para domínios nos quais a diferenciação entre cidadãos apenas favorece a prática de crimes.

É óbvio que há um grande debate a ser travado em torno da questão da responsabilidade e de como aferi-la de maneira racional. O problema não está em discutir a questão, em expô-la 
ao espaço público, mas sim em negar-lhe pertinência política e tratá-la apenas como uma questão de penalidade. Os defensores de um individualismo extremado, que nega qualquer possibilidade de diferenciação entre indivíduos a partir de seu estágio de maturidade, acabam se esquecendo de que o próprio Mill afirma no começo de seu livro que: “Talvez seja quase desnecessário dizer que essa doutrina pretende aplicar-se somente aos seres humanos de faculdades maduras. Não nos referimos a crianças ou jovens abaixo da idade fixada pela lei para a emancipação masculina ou feminina. Aqueles cuja condição requer ainda a assistência alheia devem ser protegidos contra suas próprias ações da mesma forma que contra as injúrias alheias" (ibidem, p. 54).

Os ataques às leis de proteção à infância e à adolescência não podem, assim, reivindicar sem mais uma herança liberal, baseando-se apenas na afirmação da base individual de nossa sociabilidade e na defesa de uma concepção de liberdade negativa como a de não interferência na esfera individual como a única aceitável. Mesmo para um pensador liberal e utilitarista, é necessário proteger uma parte do corpo político para que ele preserve sua liberdade. O que emerge, portanto, da opinião pública não é uma defesa da liberdade em sua forma liberal, mas sim a nostalgia de um direito que se exerce sem limites.

No campo da penalidade tudo se passa como se quiséssemos voltar ao que Foucault chamou de "suplício judiciário" (Foucault, 1975, p. 51). Punir o corpo e a alma por meio da exposição ao público da falta cometida e da pena atribuída passou a ser nos séculos XVII e XVIII uma maneira de fazer ver o que podia a justiça e o destino reservado aos que a desafiavam. O importante no movimento, que segundo o pensador francês vai conduzir à generalização da prisão como forma de punição no século XIX, é que a cada vez que se pune alguém o que é exposto e julgado é muito mais do que aquilo que motivou a operação do mecanismo corretivo. Aos poucos como diz Foucault: "Toda a operação penal se carregou com elementos e personagens extra-jurídicos" (ibidem, p. 27). Não se quer saber apenas o que ocorreu, mas como o crime pode ocorrer, de que forma ele podia ter sido previsto ou 
$\mid 46$ |

Republicanismo, constituição e percepção...

até mesmo evitado. No movimento em direção à prisão como forma por excelência de punição, mudou-se também do exercício da justiça corretiva como afirmação da força do soberano para uma concepção da punição como uma forma de restituição do sujeito ao universo do direito por meio da reordenação de suas pulsões (ibidem, p. 133).

Devolver, pela prisão, o criminoso ao respeito das regras do direito, domar seu corpo e reduzi-lo a uma disciplina adequada à ordem social, implica na necessidade conhecer os processos sociais, mas também biológicos, que o conduziram ao crime. Importa desvelar o cenário pessoal de formação do ato transgressor, para torná-lo inteligível aos que devem puni-lo. É nesse contexto que a infância vai interessar à justiça corretiva. Na lógica do direito penal moderno há em germe na criança o cidadão criminoso. Como resume Foucault: "[...] quando se quer individualizar o adulto sadio, normal e legalista, é sempre a partir de então lhe perguntando o que nele resta da criança, por que loucura secreta ele é habitado, qual crime fundamental ele quis cometer" (ibidem, p. 195). Não há, pois, espaço para uma infância outra do que aquela suposta pelas técnicas de amestramento do corpo pelas quais o poder penal passou a ser exercido. Deixar de lado um período da vida como potencialmente perigoso é abdicar de uma parte do poder que toda sociedade concede aos seus executores penais.

Surge, assim, na contemporaneidade, a figura da criança marginal, que prefigura o criminoso irremediável. É desse imaginário punitivo que emerge o medo de uma infância que já contém os germes de sua perdição e que não poderá ser recuperada. Ou melhor, ela poderá ser domada, se, como mostra Foucault, seu corpo for controlado, suas pulsões contidas nos limites da lei. A opinião pública, com muita frequência, retém essa imagem da inexorabilidade das práticas delituosas ao incorporar a ideia moderna da punição ideal pela prisão, na impossibilidade da reedição dos suplícios, como a última barreira contra uma violência que parece ameaçá-la de todos os lados. 
A literatura soube captar, até antes do surgimento da sociologia e da psicologia contemporâneas, a realidade dessa ameaça difusa, que para alguns paira sobre a cidade, que deixa de prestar atenção às margens nas quais o crime surge e se espalha. Nesse território de todas as transgressões, não há lugar, no imaginário de muitas das sociedades atuais, para nada além do monstruoso e do terrível. Uma infância vivida nessas condições será um perigo a ser conjurado, se quisermos evitar que a lei sucumba às boas intenções de alguns legisladores. No Brasil, Jorge Amado soube com seus Capitães de areia restituir a riqueza das vidas gestadas nas franjas externas da miséria, mas foi Victor Hugo, em Os miseráveis, quem primeiro compreendeu a verdadeira natureza do drama que se encenava muito antes de falarmos de direitos das crianças e dos adolescentes.

Ao narrar parte da vida do pequeno Gavroche, Hugo mostrou que nas regiões miseráveis das cidades não há como evitar o contato das crianças e adolescentes com o crime. Gavroche estava habituado com o convívio dos grandes marginais de Paris. Instado por Montparnasse, bandido conhecido pela polícia da cidade, ele ajudou na fuga de um homem, que revelou ser seu pai, que o abandonara ainda pequeno. Hugo não tinha ilusões quanto à vida que esperava aqueles que eram expulsos para as margens da cidade. Nesse sentido, não inventava uma infância pura e nem desconhecia os riscos impostos pela condição de marginalidade a que estavam submetidos. Mas ele reconhecia que se tratava de um fato social, que estava longe de poder ser reduzido a alguns poucos elementos. É a complexidade da condição humana, expressa numa infância perdida na cena urbana, que o interessa. Ele não deixa de criticar o sistema penal de seu tempo, dizendo: "Que nos permitam de interromper aqui e de lembrar que estamos na simples realidade e que há vinte anos os tribunais correcionais tiveram de julgar, sob a acusação de vagabundagem e de depredação de um monumento público, uma criança que foi surpreendida dormindo no interior do elefante da Bastilha" (Hugo, 1967, p. 485). Nesse mesmo lugar, no interior do corpo apodrecido de uma estátua que nunca foi erigida, Gavroche erigiu 
|48 |

Republicanismo, constituição e percepção...

seu lar e seu bastião contra os perigos da cidade. Nele, ele passou a constituir sua identidade de habitante de segunda categoria de um espaço urbano que ele conhece como poucos.

Hugo, sensível à dimensão criativa do lugar social ocupado pelos pequenos deserdados, chega a fazer o elogio da inutilidade de alguns equipamentos urbanos, que, no lugar de realizar um projeto qualquer, são apropriados por uma vida urbana desgarrada. "O utilidade do inútil - exclama ele - caridade das grandes coisas, bondade dos gigantes! Esse monumento desmesurado que havia contido um pensamento do imperador se transformou na caixa de um menino" (ibidem, p. 487). É a dimensão criativa de uma vida vivida nas margens que ele explora sem sentimentalismos, mas também sem fatalismos. A liberdade da qual goza Gavroche é de outra natureza do que aquela consagrada pelo direito. Ela está muito próxima da licença e da anarquia, mas não pode ser confundida com uma noção de destino ou de inexorabilidade da condição humana, que condenaria todos os deserdados ao crime e à violência. Não se trata de idealizar a condição de Gavroche, que poderia perfeitamente se tornar um criminoso, como aqueles que ele conhecia. Mas havia em sua apropriação da cidade, em sua compreensão do funcionamento de suas entranhas, um apelo a uma dimensão da política que aqueles que estão mergulhados nas engrenagens ordinárias da vida em comunidade têm dificuldade em reconhecer. Mais uma vez, a vida na margem faz surgir outro sentido para sua existência ao nos colocar diante da cena de constituição simbólica do corpo político. Com esse movimento abrimos espaço para a interrogação do sentido do momento de fundação do corpo político. Olhando para Gavroche como para um destino triste a ser realizado, não nos damos conta da fragilidade das obras humanas e nem para o fato de que elas são o produto de momentos nos quais foi preciso romper como fluxo inexorável das coisas, para construir um mundo com o rosto dos homens.

Nossa questão é saber se não podemos pensar diferentemente o problema da margem, também no que toca à questão da 
liberdade. Mais uma vez é preciso recordar que em momento algum estamos buscando uma justificativa ad hoc para a prática de crimes violentos e nem sugerindo uma visão benigna de uma situação de exclusão que está eivada de sofrimento. O que queremos é apenas compreender a relação da infância e da adolescência com os fundamentos do direito e suas repercussões para a vida ordinária. De alguma maneira, parece-nos que no cenário conturbado de nossas cidades, ao evocar o problema da violência e da exclusão, que afetam parte de nossas crianças e jovens, estamos no perguntando pela origem da lei e pelo sentido de nossas vidas em comum, numa lógica diferente dos que pensam a justiça apenas na lógica da penalidade.

No século XX Hannah Arendt foi uma das pensadoras que souberam enfrentar o desafio de compreender a natureza dos atos de fundação do corpo político e sua relação com a liberdade. Sua obra está toda ela atravessada pela interrogação sobre o aparecimento do novo na cena pública e na maneira como isso afeta nossa compreensão da natureza dos atos livres. Em a Vida do Espírito, o problema aparece sob a forma do questionamento da identificação entre liberdade e livre-arbítrio. Não se trata evidentemente de negar a liberdade da consciência, mas de constatar os limites de tal associação. Mostrando como a ideia de livre-arbítrio nos conduz a uma região do ser na qual o mundo em sua exterioridade não pode afetar-nos de maneira decisiva, ela pergunta: "A confiança na necessidade, a convicção de que tudo está como previsto, não é preferível a uma liberdade que paga o preço da contingência?" (Arendt, 1983, p. 225).

Ao adotarmos um conceito de liberdade que ela chama de "filosófica", estamos na verdade escolhendo pensar algo "que se aplica exclusivamente às pessoas que vivem fora dos grupamentos políticos, como indivíduos solitários" (ibidem, p. 228). O giro que a pensadora propõe em relação à tradição, que imperou entre bom número de filósofos na modernidade, é o de retornar a uma concepção da liberdade que envolva necessariamente a pluralidade dos que habitam o corpo político, e se refira a fenômenos que potencialmente podem afetar a todos, e não apenas ao eu pensante 
|50|

Republicanismo, constituição e percepção...

(ibidem, p. 229). Diferentemente da liberdade que se refere a fenômenos da consciência, a liberdade política é sempre limitada, pois opera num mundo no qual é impossível uma total convergência de desejos. Surge daí o fato de que os atos livres, praticados na cena pública, estão sempre sujeitos à contingência, não podem ser geridos como um processo automático de produção de sentido. Sobre eles podemos falar de seu começo, mas nunca prever inteiramente seus resultados. Ora, é da contingência que queremos fugir quando preferimos a ordem suposta da justiça penal ao burburinho perigoso da cidade, que coloca em questão seus fundamentos a cada vez que as malhas do ordinário são rompidas. Daí nossa dificuldade para pensar processos sociais que parecem ameaçar nossa tranquilidade exatamente por recordar a dimensão humana da criação das leis.

O que Hannah Arendt nos ajuda a pensar é a natureza dos atos que criam as sociedades políticas e suas leis fundamentais. Se em toda Constituição há uma esfera de intervenção exclusiva da razão, e um espaço para a transmissão da tradição jurídica na qual nos inserimos, há também uma parte de indeterminação e de contingência. Ao fundarmos uma nova sociedade, ou ao reformularmos suas bases, estamos necessariamente correndo riscos, nos expondo ao perigo da liberdade e do novo. Não há como fundar e fugir das consequências da instauração de algo que demole nossas certezas e questiona nosso passado. Toda lei que altera nossa visão da ordenação das forças principais do Estado nos lembra o ato de fundação, durante o qual se confundem a vontade de inscrever na história um novo sentido para nossa existência em comum e o medo pelo que virá, pois, como afirma Arendt, "é da natureza mesma do começo de abrigar em si um elemento de arbitrário total" (ibidem, p. 236).

Arendt nos ajuda a desvelar nossos medos com relação ao estabelecimento de leis que mudam a relação de parte dos membros do corpo político com sua Constituição, ao mesmo tempo em que nos esclarece quanto ao lugar que a liberdade ocupa nos atos que fogem da esfera de normalização da vida. Não se trata 
de transformar os pequenos Gavroche em legisladores plenipotenciários. No turbilhão de suas vidas, é perfeitamente possível que elas se percam na violência ou na exaustão. $\mathrm{O}$ que há de especial em sua vida nas margens da lei é que ela é capaz de nos despertar para o problema da origem do corpo político e para a contingência que a acompanha. Livre em seus movimentos por uma Paris que o rejeita e o teme. Vivendo nas entranhas de seus dejetos, convivendo desde pequeno como o crime e a ameaça, Gavroche não pode se dar ao luxo de se refugiar em sua consciência satisfeita com seus movimentos internos. Sua vida transcorre em uma fronteira sempre extrema e aberta. Ele encara cotidianamente a sobrevivência de seu corpo físico como um desafio. Daí seu orgulho, na cena em que recolhe nas ruas seus pequenos irmãos, em poder sustentar-se por uma noite com o dinheiro que conseguiu por meios escusos. Mesmo fora da prisão e das mãos da polícia, é em torno do corpo e de sua sobrevivência que se trava a batalha pela existência. Nesse sentido, é como se o biopoder, que Foucault enxergava como a nova expressão das instituições de repressão como a prisão, tivesse escapado do quadro institucional, para tentar impor seu império nos desvãos da sociedade.

Mas o poder de eliminar, ou constranger o corpo aos seus limites, operando pela fome e pela miséria constante, não é suficiente para apagar o desafio lançado pela simples existência de novos habitantes nesse planeta, que, mesmo em condições extremas, nasceram capazes de exercer sua liberdade. A margem habitada pelos pequenos Gavroche nos lembra um sentido da liberdade no qual essa afirmação pode fazer sentido. Desse lugar incômodo das origens surgem as obras que alteram o curso de nossa existência coletiva. Com isso não se está dizendo que aja uma prioridade ética dos confins da fundação do corpo político, mas sim que a simples existência de conflitos, que as leis ordinárias não dão conta de regular, senão quando apelam para a violência das Erínias, é a mostra da força de uma liberdade que nos confronta com nossos limites e nossos riscos. Ao alterar nossa concepção da relação das crianças e dos adolescentes com a lei, alteramos também nossa concepção da 
$|52|$

Republicanismo, constituição e percepção...

liberdade. Nesse universo aberto à criação, não podemos nos contentar com a liberdade entendida como livre-arbítrio e nem mesmo com a liberdade dos liberais. É enquanto potência criativa que a vida nas margens da lei nos ajuda a compreender que essas mesmas leis são o fruto do exercício livre de nosso poder de inventar nossas sociedades, e que não pode ser suprimido se não quisermos apagar a face humana de nossas instituições, para substituí-las por mecanismos automáticos dos quais não mais reconhecemos as origens. Como mostra Lefort: "é na reivindicação daqueles que são excluídos dos benefícios da democracia que ela encontra seu mecanismo mais eficaz" (Lefort, 1972, p. 390).

\section{Bibliografia}

ARENDT, H. La vie de l'esprit. Le vouloir. Paris: PUF, v. II, p. 225, 1983.

ARISTOTE. Éthique à Nicomaque. Paris: J. Vrin. Tradução: J. Tricot, 1131a25, p. 228, 1987.

ESCHYLE. "Les Eumenides". In: Theatre Complet. Paris: Garnier Flammarion, pp. 205-234, 1964.

FOUCAULT, M. Surveiller et punir. Paris: Gallimard, pp. 27-35, 1975.

GERNET, L. Droit et institutions en Grèce antique. Paris: Flammarion, p. 112, 1982.

HUGO, V. Les Misérables. Paris: Garnier-Flammarion, v. II, p. 485, 1967.

LEFORT, C. Le travail de l'oeuvre. Maquiavel. Paris: Gallimard, p. 390, 1972.

MILL, J. S. Sobre a liberdade. Petrópolis: Vozes. Tradução: Alberto da Rocha Barros, p. 51, 1991.

RICOEUR, P. Le juste, la justice et son échec. Paris: L'Herne, 2005. 
ROUSSEAU, J-J. Do Contrato Social. São Paulo: Penguin/ Companhia das Letras. Tradução: Eduardo Brandão, 2011.

WOLFF, F. "Justiça, estranha virtude...". In: NOVAES, Adauto (org). Vida. Vício. Virtude. São Paulo: Edições SESCSP, pp. 6769, 2009. 